\title{
25. GEOCHEMISTRY OF CARBON: DEEP SEA DRILLING PROJECT LEG 41
}

\author{
J.G. Erdman and K.S. Schorno, Phillips Petroleum Company, Bartlesville, Oklahoma
}

\section{INTRODUCTION}

Eleven core sections taken at Site 368 on DSDP Leg 41 from the Cape Verde Rise (Figure 1) were analyzed for organic content. The samples represent the full suite of cores taken for organic geochemical study for this site. The data provide information on depth control of the organic composition.

\section{SAMPLING AND STUDY PROCEDURES}

The core samples were collected in their plastic liners, frozen onboard ship, and remained frozen thereafter. A channel was cut down two sides of the plastic liner of each frozen core section with a milling machine to split the liner, and an aspirator was used to remove chips of plastic. All parts of the milling machine which could come in contact with the sample were washed with methylene chloride to eliminate any possible oil contamination. The channels were cut so that only a millimeter or so of plastic remained. The final cut severing the liner and cutting the core longitudinally was made with a band saw, the blade of which had also been cleaned with methylene chloride.

The flat surfaces of the core section were smoothed using the milling machine for description and photographing while the cores were still frozen. Photographs of the cores, diagrams of textural or color patterns, and brief lithological descriptions are contained in Figures 2 through 12. The sections are oriented in the photographs with the top of the core located near the zero point of the scale.

Chip samples, 10 to $20 \mathrm{mg}$ in size, of each textural type and color were removed for determination of carbonate carbon and organic carbon content. These values are listed in Table 1. The procedures for separation and analysis of these samples have been described previously (Erdman and Schorno, in press).

\section{RESULTS AND DISCUSSION}

Numerical data for the homogenized samples are provided in Tables 2 through 4 and Figure 13. Table 2 gives depth and ages of each core, the average carbonate and organic carbon content of the core sections, the proportions of the organic fraction consisting of lipids and kerogen, and the carbon isotopic ratios of the lipid and kerogen fractions. Table 3 contains the nitrogen composition of the dried core as determined by the full- and half-Kjeldahl methods. Table 4 provides the normalized composition of saturates, aromatics and asphaltics fractions, the elemental composition of carbon, hydrogen, nitrogen, sulfur, and oxygen in the lipid fractions, and the mole ratios of hydrogen to carbon.

The lithologies of these sediments range from clay and claystone in the Upper Cretaceous to calcareous ooze in the upper Miocene and Plio-Pleistocene.

The organic content is relatively uniform averaging 1.1 weight percent with a range of 0.3 to 2.7 . Only the Paleocene Core 368-51-2 contained insufficient amounts of organic matter to support petroleum genesis.

Lipid makes up $1 \%$ to $3 \%$ of the total organic matter for 9 of the 11 cores which falls within the range of most DSDP samples studied in this laboratory. The Upper Cretaceous Section 368-63-3 contains three to five times as much lipids as the remaining cores. The increase in lipids reflects the increased rate of petroleum genesis due to the injection of a diabase sill at 957 to 970.5

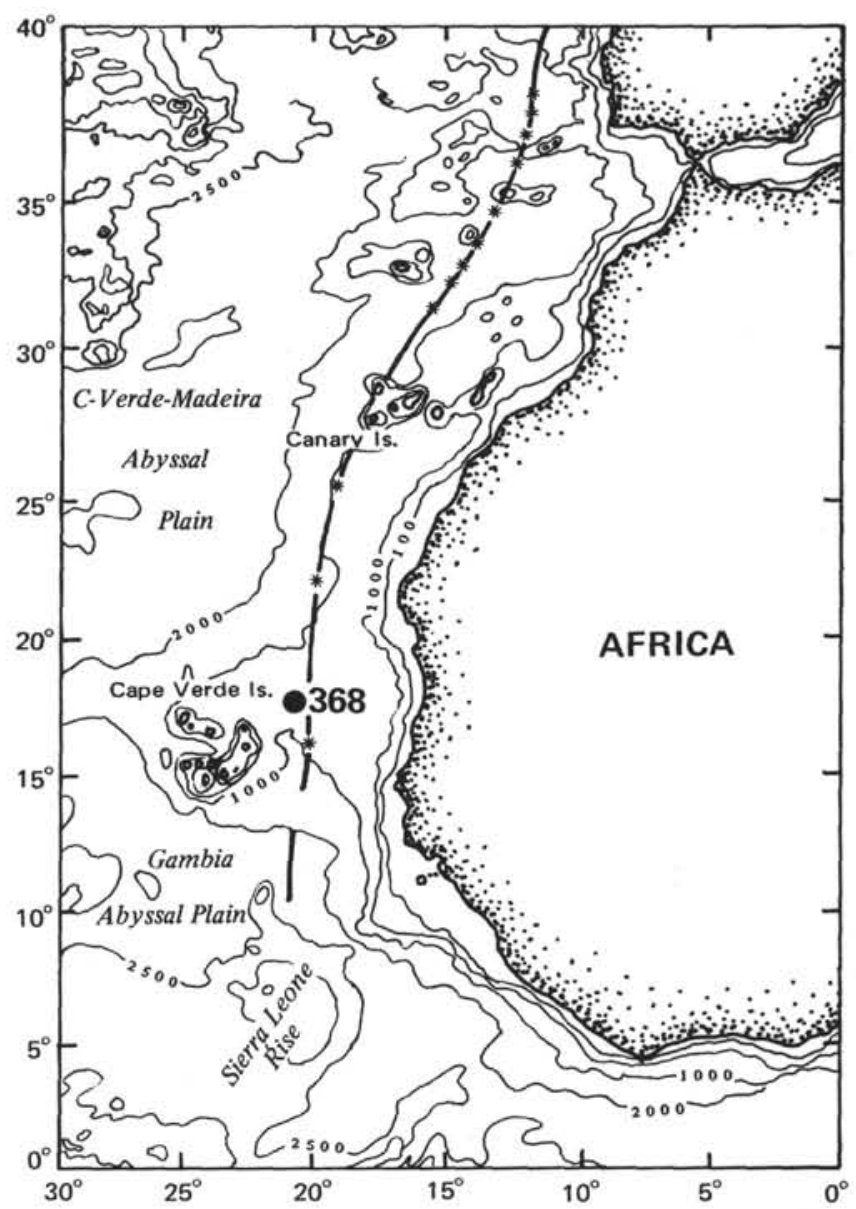

Figure 1. Location of site from which samples for geochemical study were obtained. 


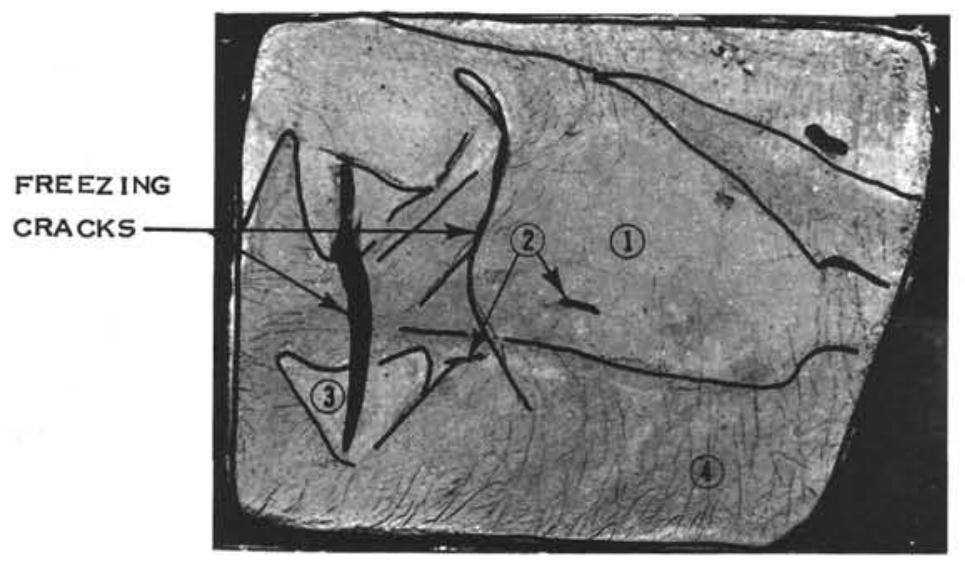

Figure 2. Site 368, Core 3, Section 5. Foraminiferal ooze, light olive-gray (5Y 6/1), highly calcareous. Foraminifers abundant, up to $1 \mathrm{~mm}$ diameter.

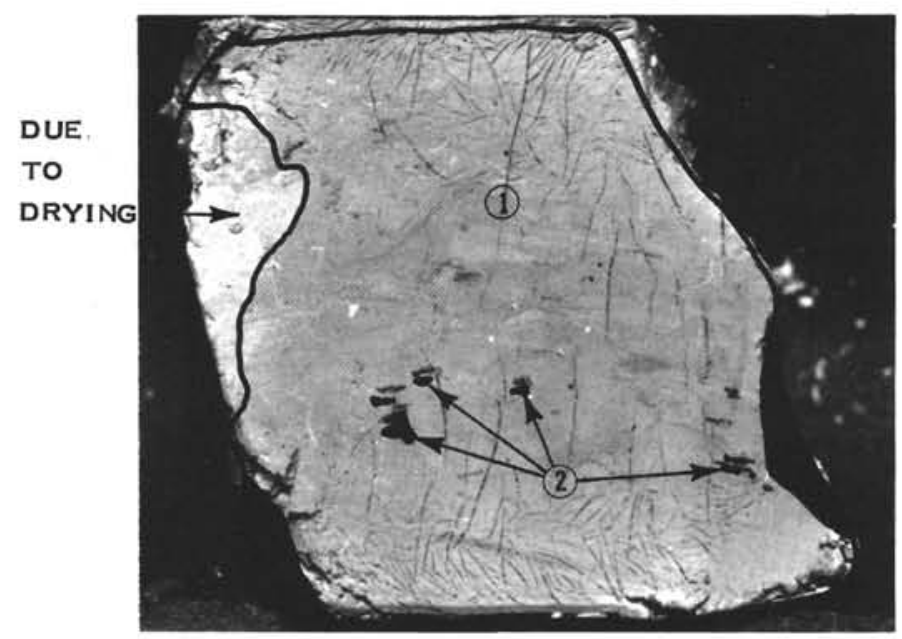

Figure 3. Site 368, Core 8, Section 3. Calcareous ooze, yellowish-gray (5Y 8/1). No fossils discernable. Clay clasts, olive-black $(5 Y 2 / 1)$.

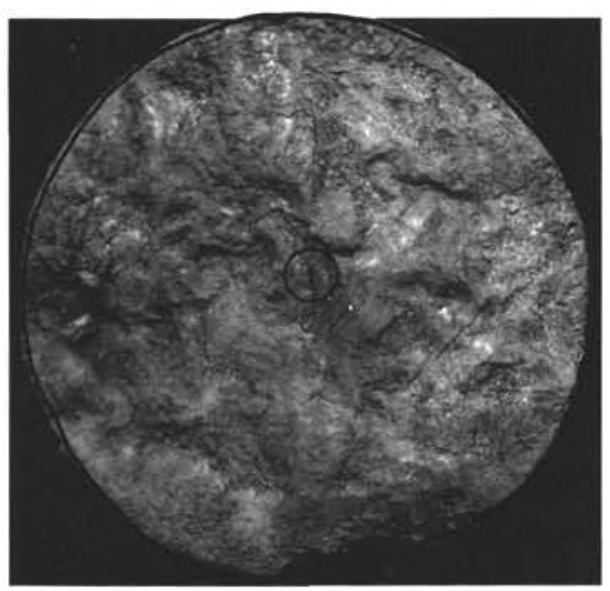

Figure 4. Site 368, Core 15, Section 3. Clay, greenish-gray (5G 6/1).

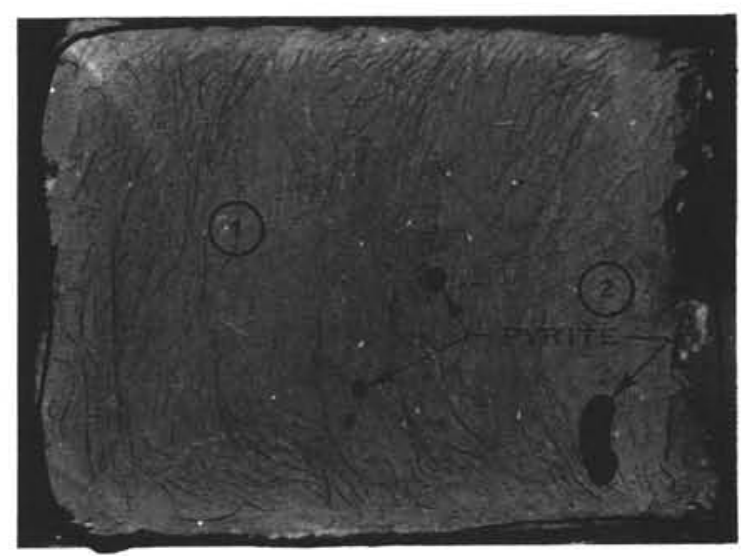

Figure 5. Site 368, Core 18, Section 5. Clay, grayish-blue-green (5BG 5/2). Contains siliceous spicules and abundant disseminated pyrite.

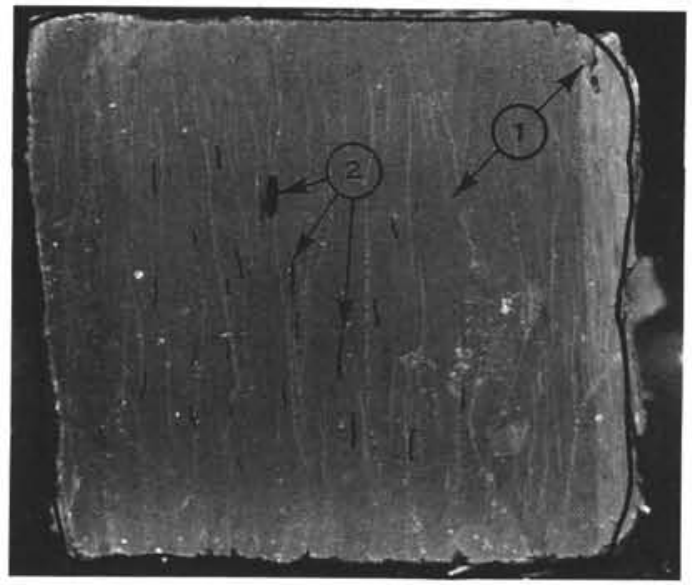

Figure 6. Clay, greenish-gray (5GY 6/1). Contains scattered pyrite. 


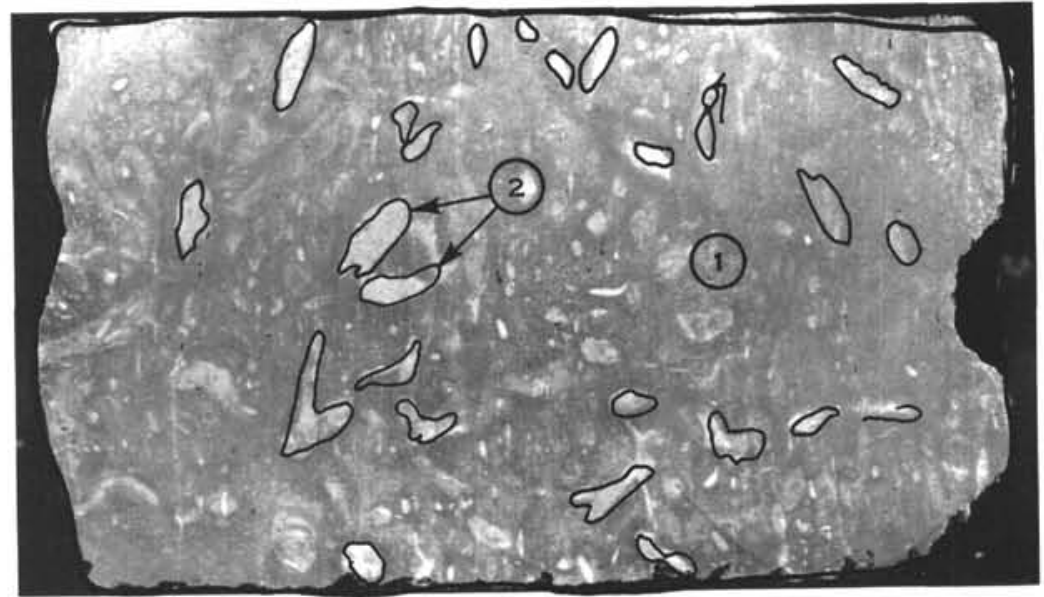

Figure 7. Site 368, Core 32, Section 2. Clay, greenish-gray (5GY 6/1) with subangular to rounded clasts of white clay to $2 \mathrm{~cm}$ pyrite present in one $5 \mathrm{~mm}$ nodule.

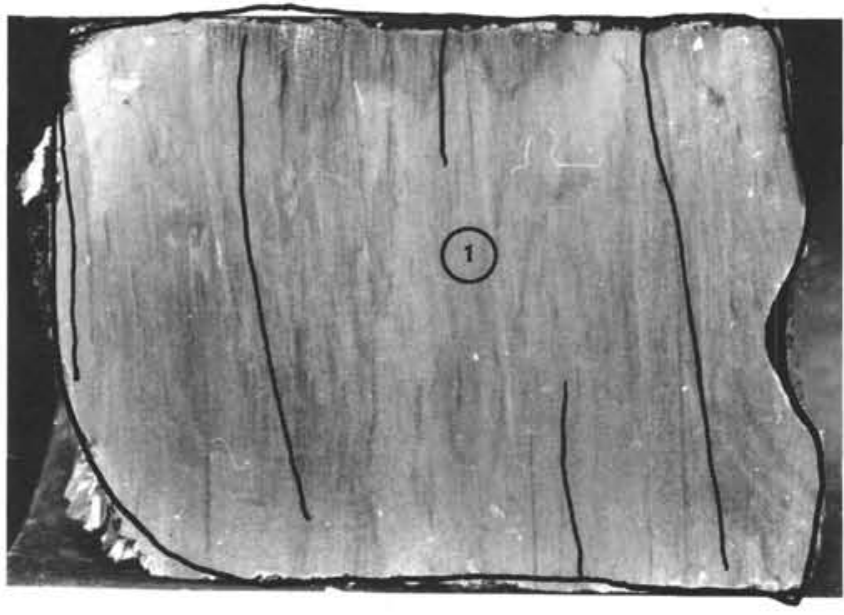

Figure 8. Site 368, Core 37, Section 3. Clay, dusty yellow-green (5GY 5/2) streaked with olive-black (5Y 2/1) along continuous bedding surfaces. Well indurated, fissile.

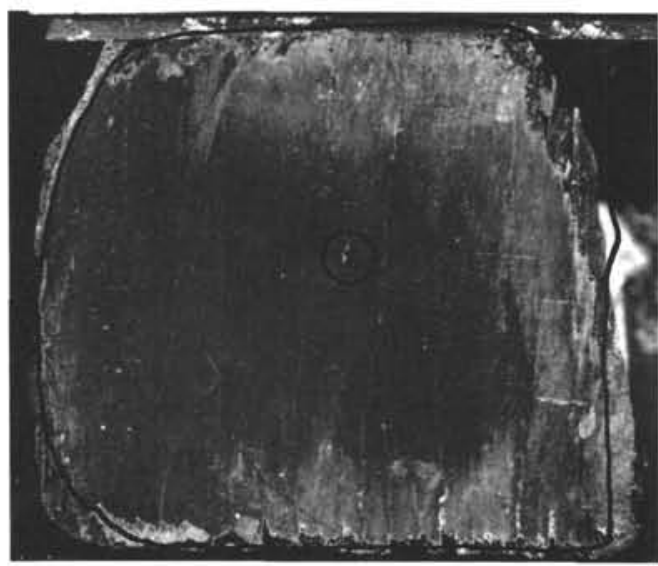

Figure 9. Site 368, Core 43, Section 2. Clay, olive-gray (5Y 4/1). Well indurated, fissile.

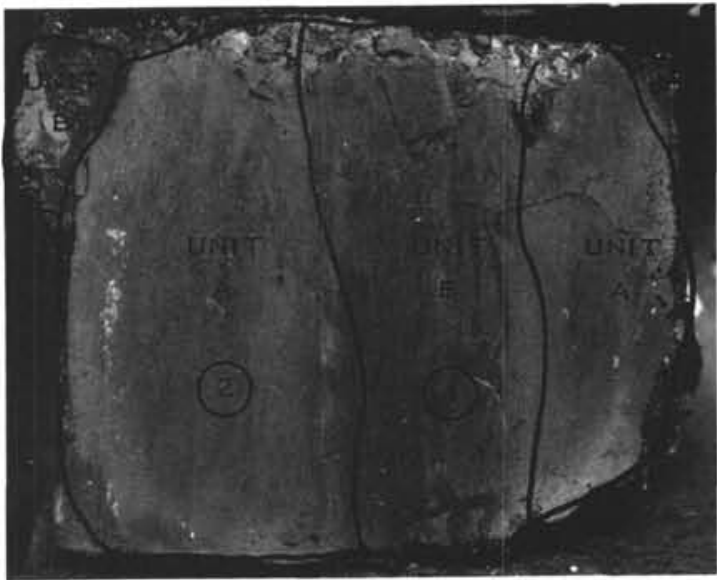

Figure 10. Site 368, Core 51, Section 2. Unit AClay, greenish-gray (5GY 4/1). Dark flecks appear to be plant macerals. Unit B-Clay, same as Unit $A$ but dark yellowish-brown (10YR 4/2).

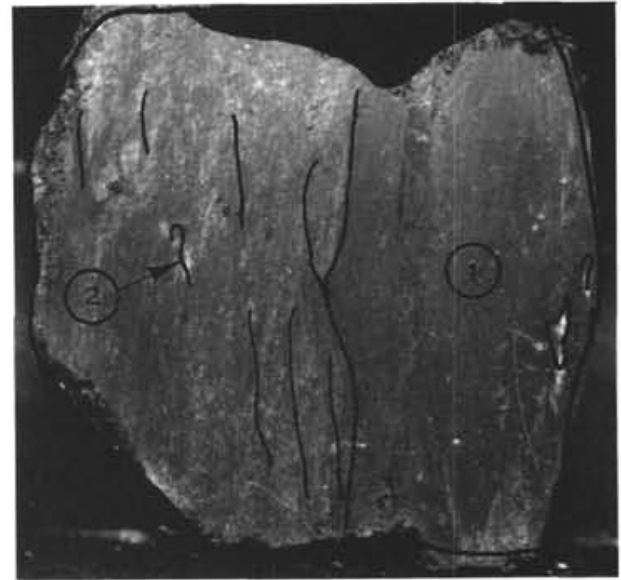

Figure 11. Site 368, Core 58, Section 4. Clay, dark greenish-gray (5GY 4/1) with light gray clasts (2). Contains scattered pyrite in $1-2 \mathrm{~mm}$ blebs. 
TABLE 1

Carbonate and Organic Carbon Values for Inclusions Noted in Figures 2-12

\begin{tabular}{|c|c|c|c|c|c|}
\hline \multirow[b]{2}{*}{ Figure } & \multirow[b]{2}{*}{$\begin{array}{c}\text { Site- } \\
\text { Core-Section }\end{array}$} & \multirow[b]{2}{*}{ Inclusion } & \multicolumn{2}{|c|}{ Carbonate } & \multirow{2}{*}{$\begin{array}{l}\text { Organic } \\
\text { Carbon } \\
\text { (wt \%) }\end{array}$} \\
\hline & & & $\begin{array}{l}\text { Carbon } \\
\text { (wt \%) }\end{array}$ & $\begin{array}{l}\mathrm{CaCO}_{3} \\
\text { (wt \%) }\end{array}$ & \\
\hline 2 & $368-3-5$ & $\begin{array}{l}1 \\
2 \\
3 \\
4\end{array}$ & $\begin{array}{c}3.45 \\
\mathrm{a} \\
5.72 \\
9.36\end{array}$ & $\begin{array}{c}28.75 \\
a \\
47.67 \\
78.00\end{array}$ & $\begin{array}{l}0.80 \\
0.50 \\
0.29 \\
0.33\end{array}$ \\
\hline 3 & $368-8-3$ & $\begin{array}{l}1 \\
2\end{array}$ & $\begin{array}{c}8.71 \\
a\end{array}$ & $\begin{array}{c}72.58 \\
a\end{array}$ & $\begin{array}{l}0.27 \\
0.56\end{array}$ \\
\hline 4 & $368-15-3$ & 1 & 4.80 & 40.00 & 0.92 \\
\hline 5 & $368-18-5$ & $\begin{array}{l}1 \\
2\end{array}$ & $\begin{array}{c}0.17 \\
\mathrm{a}\end{array}$ & $\begin{array}{c}1.42 \\
\mathrm{a}\end{array}$ & $\begin{array}{l}1.56 \\
2.00\end{array}$ \\
\hline 6 & $368-27-2$ & $\begin{array}{l}1 \\
2\end{array}$ & $\begin{array}{c}<0.1 \\
2.03\end{array}$ & $\begin{array}{l}<0.83 \\
16.92\end{array}$ & $\begin{array}{l}0.99 \\
1.50\end{array}$ \\
\hline 7 & $368-32-2$ & 1 & 0.11 & 0.92 & 0.55 \\
\hline 8 & $368-37-3$ & 1 & 2.37 & 19.75 & 0.60 \\
\hline 9 & $368-43-2$ & $\begin{array}{l}1 \\
2 \\
3\end{array}$ & $\begin{array}{l}0.20 \\
0.24 \\
0.22\end{array}$ & $\begin{array}{l}1.67 \\
2.00 \\
1.83\end{array}$ & $\begin{array}{l}0.19 \\
0.47 \\
0.47\end{array}$ \\
\hline 10 & $368-51-2$ & $\begin{array}{l}1 \\
2\end{array}$ & $\begin{array}{l}0.20 \\
0.24\end{array}$ & $\begin{array}{l}1.67 \\
2.00\end{array}$ & $\begin{array}{l}0.19 \\
0.47\end{array}$ \\
\hline 11 & $368-58-4$ & $\begin{array}{l}1 \\
2\end{array}$ & $\begin{array}{c}<0.1 \\
0.26\end{array}$ & $\begin{array}{r}<0.83 \\
2.17\end{array}$ & $\begin{array}{l}0.27 \\
0.14\end{array}$ \\
\hline 12 & $368-63-3$ & $\begin{array}{l}1 \\
2 \\
3\end{array}$ & $\begin{array}{l}<0.1 \\
<0.1 \\
<0.1\end{array}$ & $\begin{array}{l}<0.83 \\
<0.83 \\
<0.83\end{array}$ & $\begin{array}{l}1.50 \\
0.53 \\
1.30\end{array}$ \\
\hline
\end{tabular}

ansufficient sample size for determination.

meters. The Plio-Pleistocene Section 368-3-5 contains very little lipid which probably is an indication of a very early stage of petroleum genesis.

All 11 cores contain organic matter derived from marine sources as determined by the carbon isotopic ratios of the lipid fraction ranging from -28.6 to -23.7

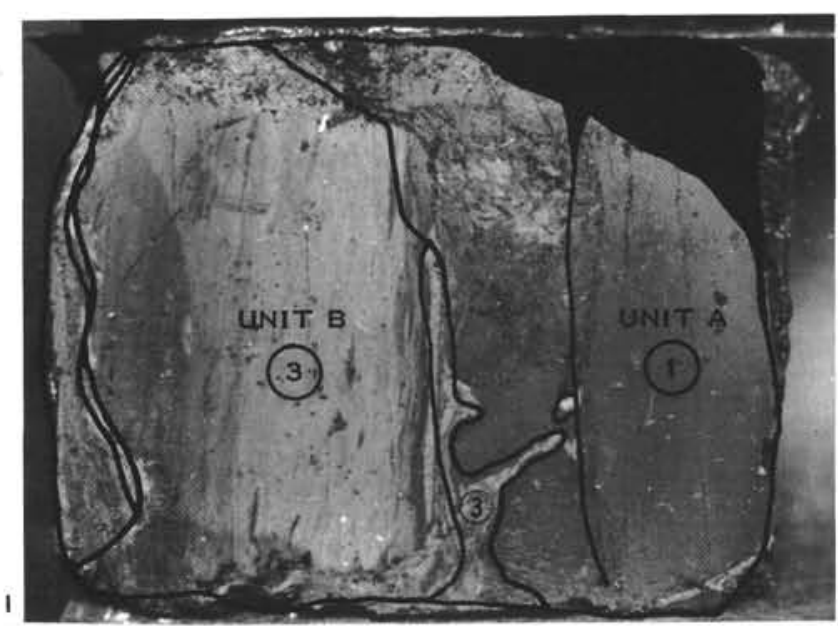

Figure 12. Site 368, Core 63, Section 3. Unit A-Clay, olive-gray (5Y 3/2), plastic. Thin laminae of light gray probably due to drilling disturbance. Unit B-Clay, dark greenish-gray (5GY 4/1).

$\delta C_{\mathrm{PDB}}^{13}$. Admixture of a considerable contribution of terrestrial organic matter into all but the two carbonate sediments is indicated by the very light carbon isotopic values for the kerogen.

Both the ammonia and total nitrogen contents are relatively constant from the Upper Cretaceous to the Oligo-Miocene Section 368-18-5 and then decrease in the younger sediments. The highest values for the ammonia and the organic nitrogen, i.e., the difference between the total nitrogen as determined by the full$\mathrm{Kjeldahl}$ and the ammonia nitrogen as determined by the half-Kjeldahl, are associated with the sediments containing the highest organic content.

The percentage of saturated hydrocarbons is relatively constant, averaging 2.7 weight percent with a range of 1.3 to 6.2 , in the Plio-Pleistocene to the lower

TABLE 2

Carbonate Content and Concentration of Organic Matter (in wt \%) and Carbon Isotopic Ratio Values of the Lipid and Kerogen Fraction (in $\delta C_{\text {PDB }}^{13}$ Units) From Geochemical Samples From DSDP Leg 41

\begin{tabular}{|c|c|c|c|c|c|c|c|c|c|c|c|}
\hline \multirow[b]{3}{*}{$\begin{array}{l}\text { Site-Core- } \\
\text { Section }\end{array}$} & \multirow[b]{3}{*}{ Geologic Age } & \multirow[b]{3}{*}{$\begin{array}{l}\text { Subbottom } \\
\text { Depth (m) }\end{array}$} & \multicolumn{5}{|c|}{ Percent of Rock } & \multirow{3}{*}{$\begin{array}{c}\begin{array}{c}\% \text { of } \\
\text { Total } \\
\text { Organic } \\
\text { Carbon }\end{array} \\
\begin{array}{c}\text { Lipid } \\
\text { Carbon } \\
(w t \%)\end{array}\end{array}$} & \multicolumn{3}{|c|}{$\begin{array}{c}\text { Carbon Isotopic } \\
\text { Composition }\end{array}$} \\
\hline & & & \multicolumn{2}{|c|}{ Carbonate } & \multicolumn{3}{|c|}{ Organic Carbonate } & & & & Diff. \\
\hline & & & $\begin{array}{l}\text { Carbon } \\
\text { (wt \%) }\end{array}$ & $\begin{array}{l}\mathrm{CaCO}_{3} \\
\text { (wt \%) }\end{array}$ & $\begin{array}{l}\text { Total } \\
\text { (wt \%) }\end{array}$ & $\begin{array}{l}\text { Lipid } \\
\text { (wt \%) }\end{array}$ & $\begin{array}{l}\text { Kerogen } \\
\text { (wt \%) }\end{array}$ & & Lipid & Kerogen & $\begin{array}{c}\text { Lipid- } \\
\text { Kerogen }\end{array}$ \\
\hline $368-3-5$ & Plio Pleist & $50.1-50.2$ & 4.37 & 36.42 & 0.65 & 0.002 & 0.65 & 0.36 & a & -21.3 & \\
\hline $368-8-3$ & U. Miocene & $181.4-181.5$ & 9.58 & 79.83 & 0.64 & 0.017 & 0.62 & 2.60 & -26.5 & -20.1 & -6.4 \\
\hline $368-15-3$ & M. Miocene & $250.1-250.2$ & $<0.10$ & $<0.83$ & 0.99 & 0.012 & 0.98 & 1.22 & -28.6 & a & \\
\hline $368-18-5$ & U. Oligo/1 Mio & $271.3-271.4$ & $<0.10$ & $<0.83$ & 0.68 & 0.009 & 0.67 & 1.31 & -26.2 & a & 13.5 \\
\hline $368-27-2$ & M. Eocene & $391.3-391.4$ & $<0.10$ & $<0.83$ & 2.12 & 0.034 & 2.09 & 1.60 & -27.8 & -29.5 & 1.7 \\
\hline $368-32-2$ & M. Eocene & $451.3-451.4$ & $<0.10$ & $<0.83$ & 1.37 & 0.013 & 1.36 & 0.95 & -26.0 & a & \\
\hline $368-37-3$ & M. Eocene & $541.4-541.5$ & $<0.10$ & $<0.83$ & 2.70 & 0.022 & 2.68 & 0.81 & -27.2 & -29.2 & 2.0 \\
\hline $368-43-2$ & L. Eocene & $611.4-611.5$ & 0.18 & 1.50 & 1.78 & 0.030 & 1.75 & 1.70 & $\mathrm{a}$ & -33.4 & 4.3 \\
\hline $368-51-2$ & Paleocene & $721.3-721.4$ & $<0.10$ & $<0.83$ & 0.35 & 0.007 & 0.34 & 2.12 & -26.2 & -27.7 & 1.5 \\
\hline $368-58-4$ & U. Cretaceous & $931.4-931.5$ & $<0.10$ & $<0.83$ & 0.79 & 0.015 & 0.78 & 1.86 & -23.7 & -31.3 & 7.6 \\
\hline $368-63-3$ & U. Cretaceous & $981.3-981.4$ & 0.25 & 2.08 & 0.97 & 0.096 & 0.87 & 9.89 & -28.1 & -29.6 & 1.5 \\
\hline
\end{tabular}

${ }^{\text {a }}$ Sample insufficient or unsuitable for this determination. 
TABLE 3

Full and Half Kjeldahl Determinations From Sediments From DSDP Leg 41

\begin{tabular}{lrr}
\hline & \multicolumn{2}{c}{ Nitrogen $(\mathrm{ppm})$} \\
\cline { 2 - 3 } Site-Core-Section & Half & Full \\
\hline $368-3-5$ & 47 & 300 \\
$368-8-3$ & 136 & 200 \\
$368-15-3$ & 15 & 200 \\
$368-18-5$ & 74 & 400 \\
$368-27-2$ & 150 & 700 \\
$368-32-2$ & 162 & 200 \\
$368-37-3$ & 262 & 700 \\
$368-43-2$ & 218 & 600 \\
$368-51-2$ & 213 & 500 \\
$368-58-4$ & 237 & 600 \\
$368-63-3$ & 221 & 400 \\
\hline
\end{tabular}

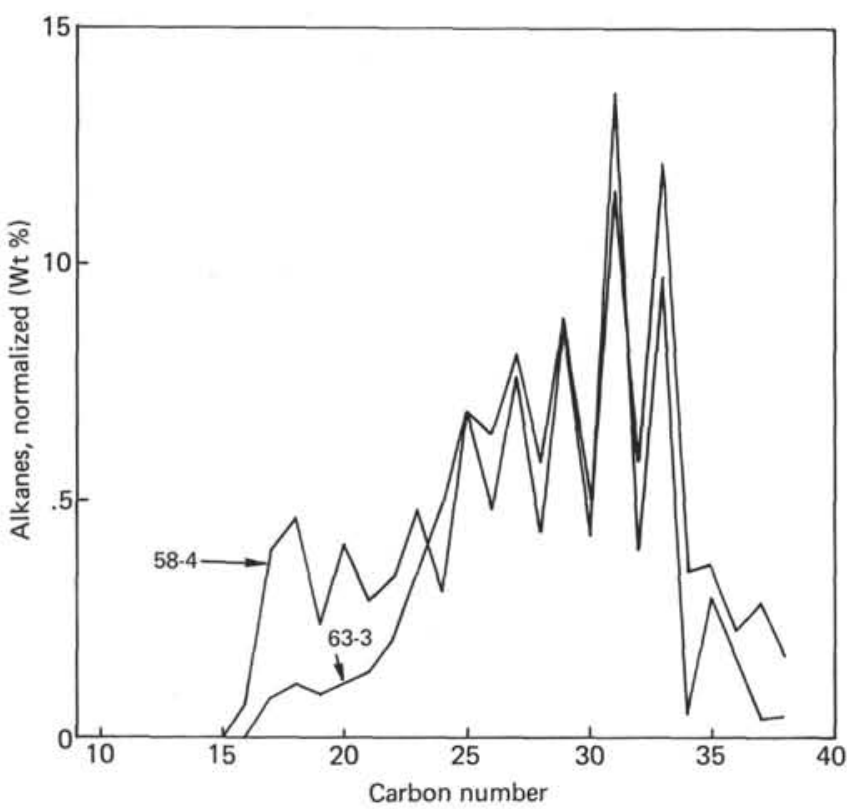

Figure 13. Normalized n-Alkanes versus carbon number plots from the Upper Cretaceous Sections 368-58-4 and 368-63-3.
Eocene sediments, then increases sharply to $16.4 \%$ and $18.6 \%$ above and below the sill in the Upper Cretaceous. The sharp increase in saturates together with a sharp decrease in the ratio of methane to ethane, as reported in the Initial Shipboard Report, gives further confirmation that the rate of catageneous of the sedimentary organic matter is influenced by proximity to the diabase sill.

The $n$-alkane distributions were obtained for the two Upper Cretaceous samples. These distributions are similar as shown in Figure 13. The differences can be attributed to either a more advanced state of petroleum genesis in the deeper core in that the odd to even preference is reduced, a different source of organic matter as indicated by the large difference in $\delta \mathrm{C}_{\mathrm{PDB}}^{13}$ of the lipid fractions, or oil migrating into these sections.

The percentage of carbon in the lipid fraction increases with depth from $74.3 \%$ in the middle Eocene to $81.8 \%$ in the Upper Cretaceous, but the percentage of hydrogen, nitrogen, and sulfur remain constant. The ratios of hydrogen to carbon, however, decrease from 1.64 (cyclohexane $=2.0$ ) to 1.57 (toulene $=1.2$ ) over this interval indicating that the lipid fraction is becoming slightly more aromatic with depth.

\section{CONCLUSION}

The organic content in these unconsolidated sediments is relatively high and in an early stage of organic diagenesis for all except the Upper Cretaceous Section 368-63-3 lying 10 meters below the diabase sill. Because the temperature effects of the sill on these sediments is localized to only 2 or 3 meters from the sillsediment interface, the changes that are observed in the lipid fraction of the Upper Cretaceous Section 368-63-3 are probably due to nonindigenous oil that had migrated from sediments lying closer to the sill.

\section{REFERENCE}

Erdman, J.G. and Schorno, K.S., in press. Geochemistry of carbon: Deep Sea Drilling Project Leg 38. In Talwani, M., Udintsev, G.B., et al., Initial Reports of the Deep Sea Drilling Project, Volume 38: Washington (U.S. Government Printing Office).

TABLE 4

Normalized Percent Composition of the Carbon, Hydrogen, Nitrogen, Sulfur, Oxygen, and Saturate, Aromatic, and Asphaltic Fractions in Core Samples From DSDP Leg 41, Site 368

\begin{tabular}{|c|c|c|c|c|c|c|c|c|c|}
\hline \multirow{2}{*}{$\begin{array}{l}\text { DSDP } \\
\text { Desig- } \\
\text { nation }\end{array}$} & \multicolumn{3}{|c|}{ Extract Fractions (wt \%) } & \multicolumn{5}{|c|}{ Elemental Composition of Total Extract (wt \%) } & \multirow{2}{*}{$\frac{\text { Hydrogen }^{\mathrm{b}}}{\text { Carbon }}$} \\
\hline & Saturate & Aromatic & Asphaltic & Carbon & Hydrogen & Nitrogen & Sulfur & Oxygen $^{a}$ & \\
\hline 3-5 & c & c & c & c & c & c & c & c & c \\
\hline $8-3$ & 1.3 & 83.4 & 15.3 & c & c & c & c & c & c \\
\hline $15-3$ & 2.2 & 77.3 & 20.5 & $\mathrm{c}$ & c & c & $\mathrm{c}$ & c & c \\
\hline $18-5$ & 6.2 & 80.0 & 13.8 & c & c & c & c & c & c \\
\hline $27-2$ & 1.8 & 56.0 & 42.0 & 74.3 & 10.2 & 0.4 & 3.7 & 11.4 & 1.64 \\
\hline $32-2$ & 1.8 & 86.0 & 12.2 & c & c & c & c & c & c \\
\hline $37-3$ & 1.9 & 67.8 & 30.3 & 74.7 & 10.3 & 0.4 & 1.0 & 13.6 & 1.63 \\
\hline $43-2$ & 4.0 & 43.0 & 53.0 & 76.7 & 11.3 & 0.8 & 4.7 & 6.5 & 1.76 \\
\hline $51-2$ & 8.7 & 78.8 & 12.5 & c & c & c & c & c & c \\
\hline $58-4$ & 16.4 & 44.3 & 39.3 & 79.1 & 10.4 & 0.3 & 2.3 & 7.9 & 1.58 \\
\hline $63-3$ & 18.6 & 54.2 & 27.2 & 81.8 & 10.7 & 0.5 & 2.5 & 4.5 & 1.57 \\
\hline
\end{tabular}

a Oxygen determined by difference.

bMolar ratio of hydrogen to carbon.

cInsufficient sample for analysis. 